\title{
ANALISIS KLASIFIKASI TINGGKAT KESEHATAN LEMBAGA PERKREDITAN DESA (LPD) MENGGUNAKAN METODE K-MEANS CLUSTERING
}

\author{
Made Agung Raharja ${ }^{1)}$ I Wayan Supriana ${ }^{2)}$ \\ Program Studi Teknik Informatika ${ }^{\text {1) 2) }}$ \\ Fakultas Matematika dan Ilmu Pengetahuan Alam, Universitas Udayana ${ }^{1)}$ 2). \\ email: made.agung@unud.ac.id ${ }^{1)}$, wayan.supriana@unud.ac.id ${ }^{2)}$
}

\begin{abstract}
Lembaga Perkreditan Desa (LPD) is one of the institutional elements of the Pakraman Village that carries out the financial functions of the Pakraman Village. In this study, research was conducted on LPDs throughout Klungkung Regency. To strengthen their trust in the LPD, the LPD needs to maintain its health level by taking into account the factors that determine the level of health itself. To measure the health of LPDs, it can be done through the information presented in the LPD's financial statements. Capital, Assets, Earning and Liquidity (CAEL) are the determinants of LPD health levels. So the writer will classify the health status of LPD in detail, in classifying the health status of this LPD, the flow method will be used according to how much the factors that are owned by each LPD in Klungkung Regency. K-means is a non-hierarchical clustering method that attempts to partition existing data into one or more clusters. The rules and methods of the $K$ Means algorithm can be applied to a program to classify data on the level of LPD health. The steps of the K-Means algorithm are translated into programming languages to perform data clustering tasks. Based on its use, the system built has been able to be used to process LPD data clustering based on the attributes of criteria in determining the health level of LPDs. This is seen from the results of testing the needs of system functionality that has been fulfilled.
\end{abstract}

Keywords : LPD health, K-Means clustering, Klungkung LPD

\begin{abstract}
ABSTRAK
Lembaga Perkredian Desa (LPD) merupakan salah satu unsur kelembagaan Desa Pakraman yang menjalankan fungsi keuangan Desa Pakraman. Pada penelitian ini dilakukan penelitian pada LPD seluruh Kabupaten Klungkung. Untuk memperkuat kepercayaannya kepada LPD, maka LPD perlu menjaga tingkat kesehatannya dengan memperhatikan faktor-faktor yang menentukan tingkat kesehatan itu sendiri. Untuk mengukur kesehatan LPD dapat dilakukan melalui informasi yang disajikan dalam laporan keuangan LPD yang bersangkutan. Capital, Assets, Earning dan Liquidity (CAEL) merupakan faktor-faktor penentu tingkat kesehatan LPD. Maka penulis akan mengklasifikasikan status kesehatan LPD secara detail, dalam pengklasifikasian status kesehatan LPD ini akan digunakan metode alur sesuai dengan berapa nilai faktor-faktor yang dimiliki oleh seiap LPD di Kabupaten Klungkung. K-means merupakan salah satu metode clustering non hirarki yang berusaha mempartisi data yang ada ke dalam bentuk satu atau lebih cluster. Aturan dan metode algoritma K-Means dapat diterapkan pada sebuah program untuk mengelompokkan data data status kesehaan LPD dan. Langkah-langkah algoritma K-Means diterjemahkan ke dalam bahasa pemrograman untuk melakukan tugas clustering data. Berdasarkan penggunaannya, sistem yang dibangun sudah mampu digunakan untuk melakukan proses clustering data LPD berdasarkan atribut kriteria dalam penentuan tingkat kesehatan LPD. Hal tersebut dilihat dari hasil pengujian terhadap kebutuhan fungsionalitas sistem yang telah terpenuhi.
\end{abstract}

Kata kunci: Kesehatan LPD, K-Means clustering , LPD Klungkung 


\section{PENDAHULUAN}

Lembaga Perkredian Desa (LPD) merupakan salah satu unsur kelembagaan Desa Pakraman yang menjalankan fungsi keuangan Desa Pakraman. Sampai saat ini LPD sangat berpotensi dan telah terbukti adalam memajukan kesejahteraan masyarakat desa dan memenuhi kepentingan desa itu sendiri, seiring dengan itu telah timbul berbagai kebutuhan baru berkenan dengan eksistensi kelembagaan, unsur-unsur manajemen, kegiatan dan operasionalnya, sehingga diperlukan analisis dan pengaturan yang lebih akurat untuk menjamin kepastian dan perlindungan hukum bagi keberadaan dan kegiatan LPD dan keberadaan Krama Desa yang menjadi anggotanya sendiri. Di Propinsi Bali sejak tahun 1985 sampai saat ini (2018) hampir setiap desa telah didirikan Lembaga Perkreditan Desa (LPD).

Untuk memperkuat kepercayaan-nya kepada LPD, maka LPD perlu menjaga tingkat kesehatannya dengan memperhatikan faktorfaktor yang menentukan tingkat kesehatan itu sendiri. Tingkat kesehatan LPD menunjukkan kemampuan untuk memanfaatkan aktiva yang dimiliki dengan produktif dan juga mampu mengatur kelangsungan usaha yang dijalankan dengan efektif, sehingga mendorong terjaminnya kontinuitas dari usaha LPD tersebut. Capital, Assets, Earning dan Liquidity (CAEL) merupakan factor-faktor penentu tingkat kesehatan LPD. LPD yang sehat dapat berpengaruh positif terhadap pertumbu-han LPD. Maka dari semua komponen inilah dapat menghasilkan kesehatan LPD khususnya di wilayah kabupaten Klungkung, untuk itu maka dipandang perlu untuk meneliti dan mengevaluasi tingkat kesehatan LPD di wilayah Kabupaten Klungkung yang terdiri dari tiga Kecamatan yaitu Kecamatan Dawan, Kecamatan Klungkung dan Kecamatan Banjarangkan.

Maka penulis akan mengklasifi-kasikan status kesehatan LPD secara detail. Dalam pengklasifikasian status kesehatan LPD ini akan digunakan metode alur sesuai dengan berapa nilai faktor-faktor yang dimiliki oleh seiap LPD di Kabupaten Klungkung. Sebelum melakukan proses klasifikasi, akan dilakukan proses pengelompokkan menggunakan metode K-Means clustering. Ada dua jenis data clustering yang sering dipergunakan dalam proses pengelompokan data yaitu hierarchical (hirarki) data clustering dan non-hierarchical (non hirarki) data clustering. K-means merupakan salah satu metode clustering non hirarki yang berusaha mempartisi data yang ada ke dalam bentuk satu atau lebih cluster. Metode ini mempartisi data ke dalam cluster sehingga data yang memiliki karakteristik yang sama dikelompokkan ke dalam satu cluster yang sama dan data yang mempunyai karateristik yang berbeda di kelompokan ke dalam cluster yang lain.

Aturan dan metode algoritma K-Means dapat diterapkan pada sebuah program untuk mengelompokkan data - data status kesehaan LPD dan. Langkah-langkah algoritma KMeans diterjemahkan ke dalambahasa pemrograman untuk melakukan tugas clustering data. Dataset dari faktor-faktor kesehatan LPD ini dimasukkan ke dalam input program, kemudian program melakukan pengolahan sesuai langkah algoritma K-Means dan hasilnya berupa cluster data. Hasil berupa cluster data inilah yang digunakan sebagai acuan faktor-faktor mana saja yang termasuk ke dalam kelompok status kesehatan LPD.

\section{TINJAUAN PUSTAKA}

\section{Konsep K-Means}

K-Means merupakan salah satu metode pengelompokan data nonhierarki (sekatan) yang berusaha mempartisi data yang ada ke dalam bentuk dua atau lebih kelompok. Metode ini mempartisi data ke dalam kelompok sehingga data berkarakteristik sama dimasukkan ke dalam satu kelompok yang sama dan data yang berkarakeristik berbeda dikelom-pokkan kedalam kelompok yang lain. Adapun tujuan pengelompokkan data ini adalah untuk meminimalkan fungsi objektif yang diset dalam proses pengelompokkan, yang pada umunya berusaha meminimalkan variasi didalam suatu kelompok dan memaksimalkan variasi antar kelompok.

Pengelompokkan data dengan metode KMeans ini secara umum dilakukan dengan algoritma seperti (Eko Prasetyo, 2012):

1. Tentukan jumlah kelompok

2. Alokasikan data kedalam kelompok secara acak 
3. Hitunglah pusat kelompok (sentroid atau rata- rata) dari data yang ada dimasing - masing kelompok

4. Alokasikan masing - masing data ke sentroid atau rata - rata terdekat

5. Kembali ke langkah 3, apabila masih ada data yang berpindah kelompok, atau apabila ada perubahan nilai sentroid diatas nilai ambang yang ditentukan, atau apabila perubahan nilai pada fungsi objektif yang digunakan masih diatas nilai ambang yang ditentukan.

Pada langkah 3 algoritma diatas, lokasi sentroid (titik pusat) setiap kelompok yang diambil dari rata - rata (mean) semua nilai data pada setiap fiturnya harus dihitung kembali. Jika M menyatakan jumlah data dalam suatu kelompok, i menyatakan fitur ke-i dalam sebuah kelompok, dan $p$ menyatakan dimensi data untuk menghitung sentoid fitur ke-i digunakan formula.

\section{METODOLOGI PENELITIAN}

Metode penelitian yang di gunakan dalam Analisis Klasifikasi Tinggkat Kesehatan Lembaga Perkreditan Desa (LPD) Menggunakan Metode K-Means Clustering mengunakan metode pengembangan perangkat lunak SDLC yaitu meliputi tahap-tahap sebagai berikut:

\section{Tahap Perencanaan (Systems Planing)}

Tahap perencanaan sistem merupakan langkah pertama dalam proses pengembangan sistem, yang terdiri dari identifikasi, seleksi dan perencanaan sistem. Mengidentifikasi kebutuhan user, yaitu Didapatkan dengan melakukan wawancara dan survei kebutuhan sistem dan pengambilan data-data di kantor LPLPD Kabupaten Klungkung yang meliputi datadata Capital, Assets, Earning dan Liquidity. Analisis kebutuhan dan tahap rancangan penelitian dilakukan dengan melaksanakan tahap-tahap sebagai yaitu Inisialisasi kebutuhan (perangkat lunak dan perangkat keras) dan analisis spesifikasi kebutuhan.

Metode pengumpulan data yang digunakan disini adalah metode wawancara dan metode observasi. Wawancara ini dilakukan dengan mencari narasumber yang ahli untuk mendapatkan data-data dari objek penelitian sedangkan metode observasi dilakukan dengan cara mencari data-data perancangan layanan sistem, perancangan arsitektur jaringan, perancangan basis data, perancangan diagram alir sistem serta perancangan antar muka sistem Klasifikasi Tinggkat Kesehatan Lembaga Perkreditan Desa (LPD) Menggunakan Metode K-Means Clustering.

\section{Analisa Sistem (Systems Analysis)}

Didapatkan dengan mencari informasi tertentu yang dapat dijadikan analisa sebagai kebutuhan pengguna dalam Sistem Klasifikasi Tinggkat Kesehatan Lembaga Perkreditan Desa (LPD) Menggunakan Metode K-Means Clustering, mencoba menentukan kebutuhan proses informasi untuk masing-masing aktivitas sistem (masukan, proses, keluaran, penyimpanan, dan kendali). Analisa sistem biasanya membutuhkan beberapa metode pemodelan data dan proses dalam peneltian unggulan ini antara lain dengan Entity Relationship Diagram (ERD) dan lain lain.

\section{Rancangan Sistem (Systems Design)}

Proses perancangan akan menerjemahkan syarat kebutuhan kesebuah perancangan perangkat lunak yang dapat diperkirakan sebelum dibuat coding. Tahap ini adalah proses untuk merencanakan atau mengatur Sistem Klasifikasi Tinggkat Kesehatan Lembaga Perkreditan Desa (LPD) Menggunakan Metode K-Means Clustering yang akan dibangun menurut tahapan tertentu sebelum sistem tersebut diwujudkan. Rancangan sistem menjelaskan sistem apa yang harus memenuhi informasi yang dibutuhkan oleh para pengguna, rancangan ini terdiri dari rancangan logika dan fisik yang dapat menghasilkan spesifik sistem yang memenuhi persyaratan sistem yang dikembangkan pada tahap Analisa.

Dari proses K-Means Clustering terdapat Algoritma K-Means, berikut algoritma KMeans dijelaskan pada gambar dibawah ini : 


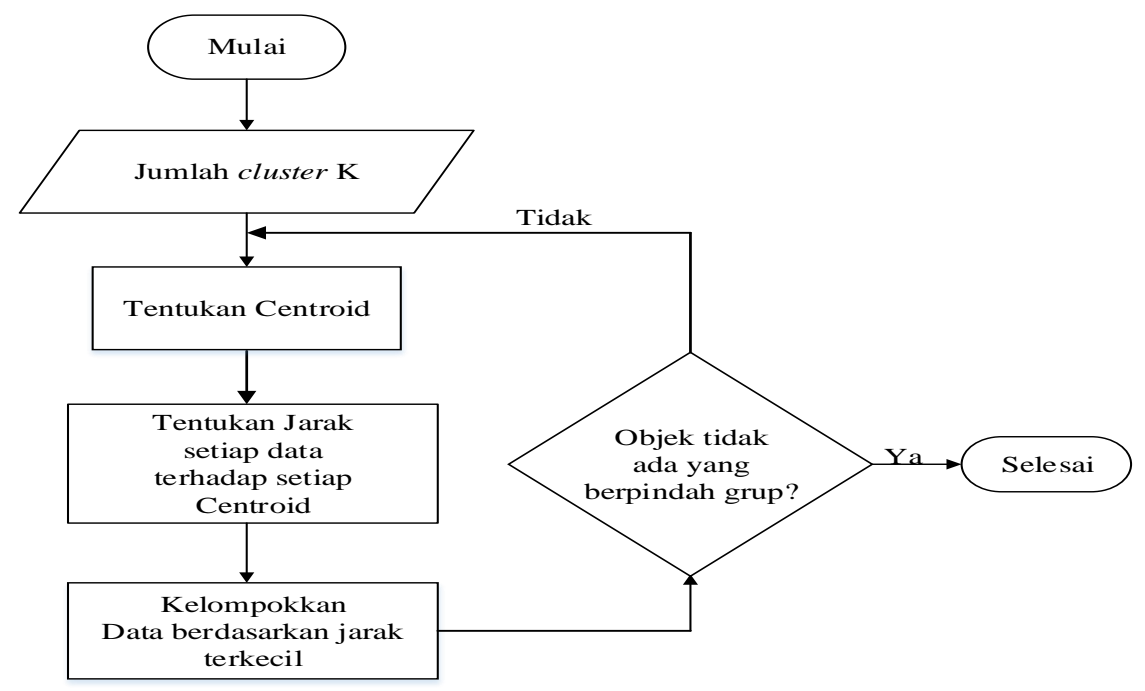

Gambar 1 Flowchart Klasifikasi Tinggkat Kesehatan Lembaga Perkreditan Desa (LPD) Menggunakan Metode K-Means Clustering

\section{Implementasi}

Tahap ini dilakukan rancang bangun sistem ke dalam suatu perangkat lunak dari model yang telah di rancang pada tahap sebelumnya. Perangakat lunak yang dipakai adalah mengunakan bahasa pemrograman berbasis web dengan Bahasa php didalamnya. PHP adalah bahasa pemrograman script server-side yang didesain untuk pengembangan web. Selain itu, PHP juga bisa digunakan sebagai bahasa pemrograman umum. Bahasa pemrograman PHP adalah sebuah bahasa script yang tidak melakukan sebuah kompilasi dalam penggunaanya, sehingga diharapkan dapat mempermudah proses implementasi.

\section{Evaluasi Hasil dan Pembuatan Laporan Akhir}

Pada tahap ini akan dilakukan evaluasi dan validasi hasil. Evaluasi dan validasi hasil dilakukan untuk mengetahui apakah yang dihasilkan sudah sesuai dengan tujuan yang ingin dicapai. Pengujian sistemnya digunakan untuk mendapatkan hasil dari similarity yang terbesar dari setiap kasus
Klasifikasi Tinggkat Kesehatan LPD Menggunakan Metode K-Means Clustering. Hasil yang ingin didapatkan adalah akurasi dari penerapan metode K-Means Clustering dalam menentukan karakteristik masing masing tingkat kesehatan LPD di kabupaen Klungkung sesuai dengan factor-faktor yang dialami.

Hasil evaluasi di atas akan digunakan sebagai dasar untuk penarikan kesimpulan dan melakukan publikasi ilmiah. Berikut diagram Fish Bone penelitian perancangan sistem Klasifikasi Tinggkat Kesehatan Lembaga Perkreditan Desa (LPD) Menggunakan Metode K-Means Clustering dapat dilihat pada Gambar 2 dibawah ini. Secara lebih detail urutan langkah-langkah penelitian dapat dilihat pada diagram Fish Bone dibawah ini : 


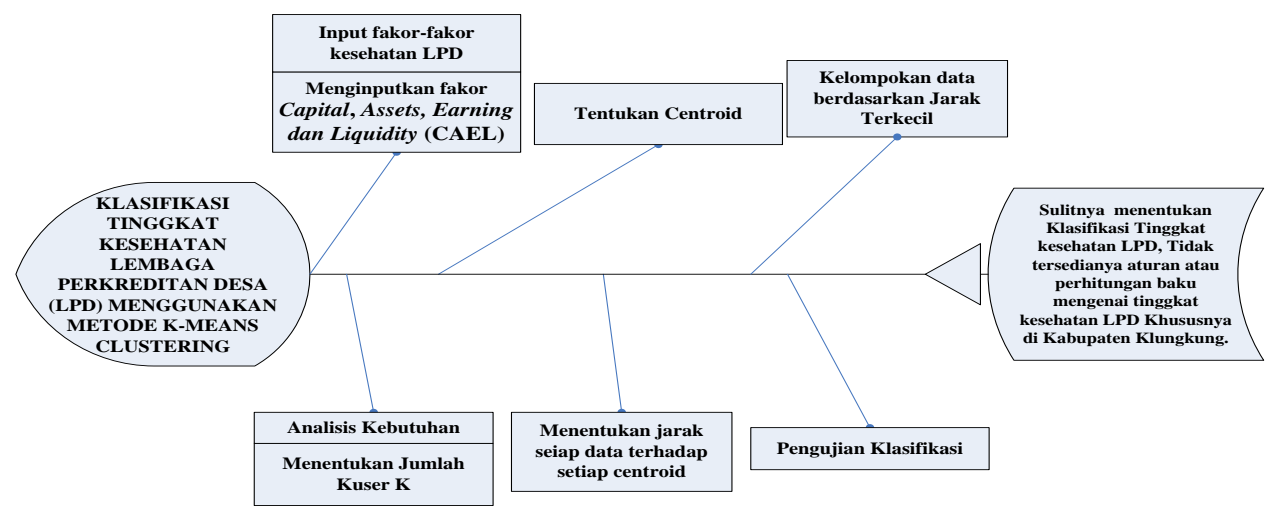

Gambar 2. Diagram Fish Bone dari penelitian yang diusulkan

\section{HASIL DAN LUARAN YANG DICAPAI}

\section{Sumber Data}

Dalam penelitian ini penulis menggunakan data yang bersumber dari Lembaga Pemberdayaan Lembaga Perkreditan Desa Kabupaten Klungkung yang selanjutnya disingkat LPLPD Kabupaten Klungkung adalah suatu lembaga yang berfungsi melaksanakan pemberdayaan LPD (Peraturan Bupati Klungkung Nomor 34 tahun 2012). Data tersebut terdiri dari periode bulanan yang diambil pada bulan Juni 2018 yang terdiri dari : Capital, Assets, Earning dan Liquidity (CAEL). Seperti yang pada Tabel 1.

\section{Analisa Input}

Input dalam sistem ini dibutuhkan untuk proses pengelompokan data clustering, input untuk proses training berupa data indikatorindikator yang berpengaruh terhadap kesehatan LPD sesuai dengan perda, data inputan terdiri dari 12 bulan yaitu pada bulan Juni pada tahun 2018 yang berjumlah 111 data LPD. Di kabupaten Klungkung terdapat total 117 LPD pada setiap kabupaten, tetapi yang berstatus tidak operasi sebanyak 6 (enam) sehingga total yang menjadi data inputan dalam sistem adalah sejumlah 111 LPD yang aktif. Seperti yang pada Tabel 1 .
Tabel 1. Tabel Data LPD Kabupaten

Klungkung (Juni 2018)

\begin{tabular}{|c|c|c|c|c|c|}
\hline $\begin{array}{l}\mathbf{N} \\
\mathbf{0}\end{array}$ & $\begin{array}{l}\text { Nam } \\
\text { a } \\
\text { LPD }\end{array}$ & Status & No & $\begin{array}{c}\text { Nama } \\
\text { LPD }\end{array}$ & $\begin{array}{c}\text { Statu } \\
\quad \mathrm{s}\end{array}$ \\
\hline 1 & Aan & Aktif & $\ldots$ & $\ldots \ldots$ & $\ldots \ldots$ \\
\hline 2 & $\begin{array}{l}\text { Anjin } \\
\text { gan }\end{array}$ & $\begin{array}{c}\text { Tidak } \\
\text { Operas } \\
\text { i }\end{array}$ & $\begin{array}{c}11 \\
5\end{array}$ & $\begin{array}{l}\text { Tri } \\
\text { Wahana } \\
\text { Eka } \\
\text { Winangu } \\
\text { n }\end{array}$ & Aktif \\
\hline 3 & $\begin{array}{l}\text { Baka } \\
\text { s }\end{array}$ & Aktif & $\begin{array}{c}11 \\
6\end{array}$ & $\begin{array}{l}\text { Tri Wana } \\
\text { Giri } \\
\text { Mandala }\end{array}$ & Aktif \\
\hline & $\ldots \ldots$ & $\ldots$ & $\begin{array}{c}11 \\
7\end{array}$ & Watas & Aktif \\
\hline
\end{tabular}

\section{Analisa Proses}

Seacara umum, proses Klasifikasi Tinggkat Kesehatan Lembaga Perkreditan Desa (LPD) Menggunakan Metode K-Means Clustering dilalui dengan beberapa tahapan yaitu Tentukan jumlah kelompok, Alokasikan data kedalam kelompok secara acak, Hitunglah pusat kelompok (sentroid atau rata- rata) dari data yang ada dimasing - masing kelompok. Alokasikan masing - masing data ke sentroid atau rata - rata terdekat. Kembali ke langkah 3, apabila masih ada data yang berpindah kelompok, atau apabila ada perubahan nilai sentroid diatas nilai ambang yang ditentukan, atau apabila perubahan nilai pada fungsi objektif yang digunakan masih diatas nilai ambang yang ditentukan. 


\begin{abstract}
Analisa Output
Output dari sistem Klasifikasi Tinggkat

Kesehatan Lembaga Perkreditan Desa (LPD)

Menggunakan Metode K-Means Clustering ini merupakan hasil mengelompokkan data yang ada ke dalam beberapa kelompok, dimana data dalam satu kelompok mempunyai karakteristik yang sama satu sama lainnya dan mempunyai karakteristik yang berbeda dengan data yang ada di dalam kelompok yang lain. Dengan kata lain, metode atau sistem ini berusaha untuk meminimalkan variasi antar data yang ada di dalam suatu cluster dan memaksimalkan variasi dengan data yang ada di cluster lainnya.
\end{abstract}

\section{Analisis Kebutuhan Sistem}

Analisis yang dilakukan pada tahapan ini untuk mengetahui kebutuhan yang harus dimiliki oleh system dan mencatat kebutuhan yang diperlukan oleh sistem klasifikasi kesehatan LPD menggunakan metode K-Means Clustering. Kebutuhan tersebut adalah kebutuhan functional dan non-functional. Kebutuhan functional pada system ini terdiri dari kebutuhan kebutuhan bagaimana system harus bereaksi pada inputan dan bagaimana perilaku system pada situasi tertentu, kebutuhan functional dapat memberikan informasi mengenai factor-faktor yang digunakan dalam penilain tingkat kesehatan LPD, pengelompokkan data sesuai dengan cluster. Sedangkan kebutuhan non-functional seperti desain antarmuka dan akurasi dari system kebutuhan - kebutuhan tersebut diperoleh dari pengumpulan data. Pada pengumpulan data ini menggunakan jenis data sekunder. Dimana data sekunder akan dirubah ke data numeric sesuai perhitungan bobot.

Dari kebutuhan - kebutuhan tersebut, maka akan ditentukan masukan yang digunakan, bagaimana alur pemrosesan dan perhitungan dari input yang akan digunakan, serta output yang akan dihasilkan atau yang ditampilkan oleh sistem dari pemrosesan masukan yang dilakukan.

\section{Diagram Aliran Data}

Pada gambar 3 rancangan diagram konteks sistem sistem Klasifikasi Tinggkat Kesehatan Lembaga Perkreditan Desa (LPD) dibawah, terdapat satu entitas eksternal yaitu admin, satu gambaran umum proses sistem Klasifikasi Tinggkat Kesehatan Lembaga Perkreditan Desa (LPD), dua aliran data masukan dari entitas ke proses sistem dan dua aliran data keluaran hasil proses sistem sistem Klasifikasi Tinggkat Kesehatan Lembaga Perkreditan Desa (LPD). Seperti yang ditampilkan pada gambar diagram konteks dibawah, terdapat entitas administrator/admin yang dapat memasukkan data objek (Nama LPD, CAEL) dan data centroid awal sebagai data masukan untuk kemudian diproses oleh sistem sistem Klasifikasi Tinggkat Kesehatan Lembaga Perkreditan Desa (LPD) dan menghasilkan output berupa data hasil clustering semua data dan diagram clustering sebagai hasil proses.

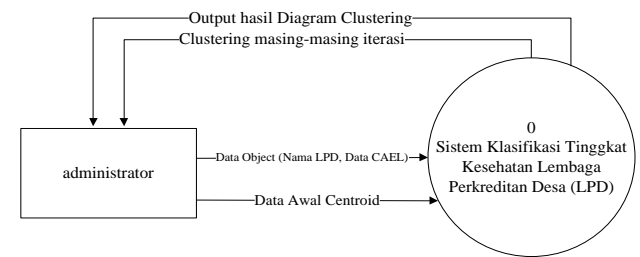

Gambar 3 Diagram konteks Sistem

\section{Rancangan Antar Muka Sistem}

Pada sub bab ini terdapat 6 rancangan antar muka untuk setiap tampilan yang akan dibuat pada sistem. Pertama akan dirancang tampilan login bagi admin LPLPD. Untuk akses Admin akan dirancang antar muka untuk tampilan dashboard sistem klasifikasi kesehatan LPD berupa tampilan Home dan profil penelitian, tampilan input data objek dan input data centroid awal, hasil clustering, tampilan diagram hasil clustering. Adapun hasil rancangan antar muka yang dibuat akan dipaparkan sebagai berikut.

Gambar 4.5 merupakan rancangan antar muka dari tampilan login pada sistem yang akan muncul pertama kali ketika sistem dibuka melalui Web Browser pengguna. Tampilan halaman awal (home) admin, merupakan tampilan awal setelah admin berhasil login ke dalam sistem. Terdapat 
tujuh buah layer yang tersusun secara sistematis kesamping, sehingga setiap layer merepresentasikan informasi yang dapat dilihat oleh admin pada halaman awal ini. Layer paling atas adalah tampilan header yang berisi logo dan navigation-bar. Pada navigation-bar terdapat sub-sub menu utama yang dapat digunakan oleh admin pada sistem. Untuk kategori menu data sistem, di implementasikan secara dropdown untuk menjaga tata letak dalam kategori sub data sistem terlihat rapi, kemudian dropdown tersebut dapat di klik di sembarang tempat untuk kembali menyembunyikanya agar tidak menggangu aktifitas sistem yang lain. Lalu dibawah header pada layer kedua terdapat gambar home screen dari sistem yang berisi ilustrasi gambar sistem. Kemudian terdapat tombol logout dipojok kanan atas navigation-bar yang dapat digunakan oleh admin untuk keluar dari sistem.

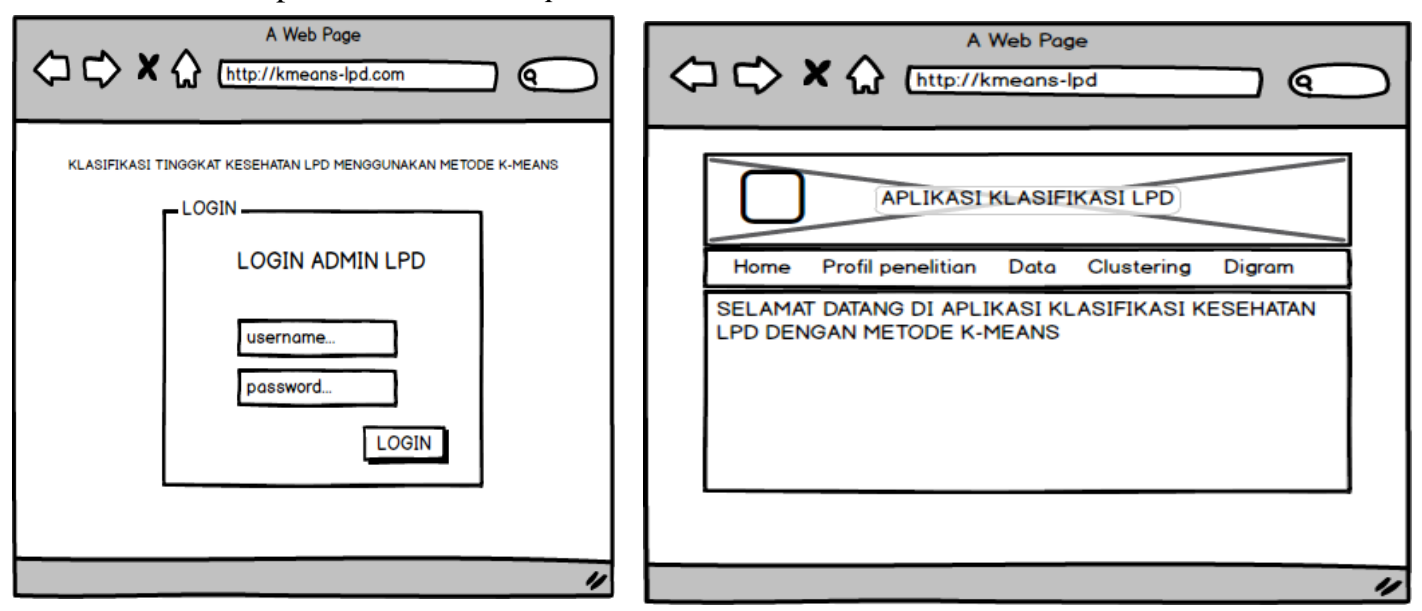

Gambar 4 Rancangan Antar Muka Tampilan Login dan Tampilan Home

\section{Implementasi Antar Muka Sistem}

Antar muka sistem yang sebelumnya sudah dirancang pada sub bab sebelumnya akan diimplementasikan ke dalam HTML, php dan CSS Berikut akan dipaparkan screenshot hasil implementasi rancangan antar muka yang dibuat ditunjukan pada sub bab berikut.

Tampilan halaman login adalah modul yang berfungsi untuk otentikasi hak akses kepada pengguna. Hanya pengguna yang telah terdaftar yang dapat mengakses sistem Klasifikasi Tinggkat Kesehatan Lembaga Perkreditan Desa (LPD). Setiap pengguna memiliki level pengguna dan setiap level pengguna memiliki batasan hak akses terhadap sistem. Level pengguna adalah admin yang dapat mengakses semua modul pada sistem termasuk modul Sistem

Klasifikasi Tinggkat Kesehatan Lembaga Perkreditan Desa (LPD)

Implementasi antar muka tampilan Input Data Objek dan Data Centroid awal memiliki dua bagian yang berada dalam satu halaman web ditunjukkan seperti yang telah dirancang dalam sub bab sebelumnya. Apabila sudah memiliki data dalam format Microsoft excel maka bias di import secara langsung, akan tetapi apabila ingin memasukkan data secara manual satu per satu juga dimungkinkan dalam aplikasi ini, tampilan secara lengkap pada Gambar 5 berikut.

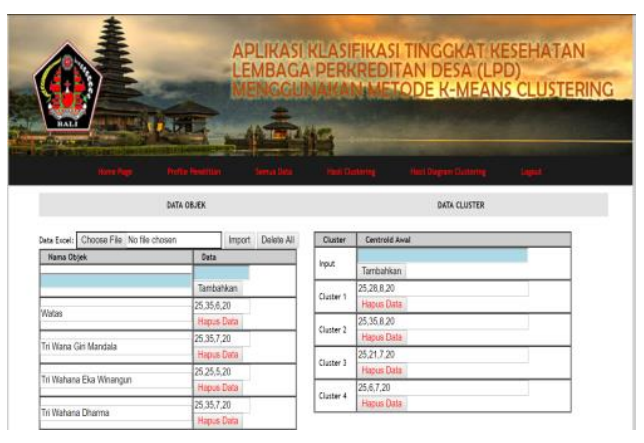

Gambar 5 Implementasi Tampilan Input Data Objek dan Data Centroid awal

\section{Pengujian dan Evaluasi}

Setelah perancangan antar muka selesai maka tahapan berikutnya adalah melakukan perancangan skenario pengujian sistem. Dalam sub bab ini akan dipaparkan 
perancangan skenario pengujian sistem menggunakan metode pengujian perangkat lunak Black Box dan evaluasi cluster terkait hasil pengelompokkan yang diperoleh menggunakan algoritma $k$-Means clustering menggunakan teknik Silhoutte Index (SI).

Pengujian Black Box borfokus pada kebuthan fungsional sistem yang sudah didefiniskan pada sub bab Analisis Kebutuhan Sistem. Pengujian dituangkan dalam bentuk tabel uji (Tabel 2).

Tabel 2 Rancangan Tabel Pengujian Black Box

Kode Kebutuhan: $\boldsymbol{K F} \mathbf{1}$

Kasus:

Melakukan pengujian validasi input pada proses login

\begin{tabular}{|l|l|l|l|} 
No. & $\begin{array}{l}\text { Skenario } \\
\text { Pengujian }\end{array}$ & $\begin{array}{l}\text { Hasil yang } \\
\text { Diharapka } \\
\mathrm{n}\end{array}$ & $\begin{array}{l}\text { Hasil } \\
\text { Pengujian }\end{array}$ \\
\hline$\ldots$ & $\ldots \ldots \ldots \ldots$ & $\ldots \ldots \ldots \ldots$ & $\ldots \ldots \ldots \ldots$ \\
\hline
\end{tabular}

Evaluasi cluster dilakukan untuk menguji validitas suatu cluster menggunakan silhouette index apakah hasil clustering data sudah sesuai dengan cluster yang ditempatinya. Sehingga dari hasil pengujian ini diperoleh akurasi seberapa banyak data yang menempati cluster sesuai dengan kedekatannya.

\section{SIMPULAN}

Berdasarkan hasil penelitian sistem Klasifikasi Tinggkat Kesehatan Lembaga Perkreditan Desa (LPD) Menggunakan Metode K-Means Clustering yang telah dilakukan, maka dapat diambil beberapa kesimpulan sebagai berikut:

Adapun tahapan yang dilalui dalam merancang suatu sistem yang mampu melakukan proses clustering data kesehatan LPD berdasarkan atribut kriteria dalam penentuan tingkat kesehatan LPD yaitu mendefinisikan fungsionalitas yang harus dimiliki oleh sistem dengan melakukan analisis kebutuhan pengguna, kemudian merancang desain sistem menggunakan pemodelan usecase diagram, DFD, Diagram Alir dan Rancangan Antarmuka. Setelah itu desain sistem yang sudah dirancang diimplementasikan ke dalam baris kode dan basis data, kemudian hasil implementasi tersebut diuji sesuai dengan kebutuhan fungsionalitas yang harus dipenuhi.

Berdasarkan penggunaannya, sistem yang dibangun sudah mampu digunakan untuk melakukan proses clustering data LPD berdasarkan atribut kriteria dalam penentuan tingkat kesehatan LPD. Hal tersebut dilihat dari hasil pengujian terhadap kebutuhan fungsionalitas sistem yang telah terpenuhi.

\section{DAFTAR PUSTAKA}

[1] Dewi, M.R, Suwara.I.K. dan Widagda, J.A 2014. "Analisis Kinerja Kesehatan LPD Dan Pengaruhnya Terhadap Pertumbuhan Aset LPD Kabupaten Badung". Jurnal Manajemen Strategi Bisnis dan Kewirausahaan Vol.8 No.1, Fakultas Ekonomi dan Bisnis, Universitas Udayana.

[2] Irtawati, A.S. 2017. "Klasifikasi Penyakit Ginjal dengan Metode KMeans". Jurnal Teknologi Terpadu Vol. 5 No. 1. 1, Teknik Elektronika. Politeknik Negeri Balikpapan.

[3] Prasetyo,Eka. 2012. Data Mining Konsep dan Aplikasi menggunakan Matlab. Yogyakarta. ANDI Yogyakarta.

[4] Prasetyo,Eko. 2014. Data Mining Mengolah Data Menjadi Informasi menggunakan Matlab. Yogyakarta. ANDI Yogyakarta.

[5] Rosenblatt. 2013. Systen Analysis and Design - Tenth Edition Shelly Cashman Series. USA: Course Technology.

[6] Suprawoto, T. 2016. "Klasifikasi Data Mahasiswa Menggunakan Metode KMeans Untuk Menunjang Pemilihan Strategi Pemasaran", Jurnal Informatika dan Komputer (JIKO) - Vol. 1, No. 1, Sistem Informasi, STMIK AKAKOM Yogyakarta. 